\title{
GIS-Based Spatial Mapping of Flash Flood Hazard in Makkah City, Saudi Arabia
}

\author{
Gomaa M. Dawod ${ }^{1,2}$, Meraj N. Mirza ${ }^{3}$, Khalid A. Al-Ghamdi ${ }^{4}$ \\ ${ }^{1}$ Survey Research Institute, Giza, Egypt \\ ${ }^{2}$ Umm Al-Qura University, Makkah, Saudi Arabia \\ ${ }^{3}$ Center of Research Excellence in Hajj and Omrah, Umm Al-Qura \\ University, Makkah, Saudi Arabia \\ ${ }^{4}$ Geography Department, Umm Al-Qura University, Makkah, Saudi Arabia \\ E-mail:dawod_gomaa@yahoo.com,meraj@mmirza.com, \\ kaghamdi@uqu.edu.sa \\ Received March 29, 2011; revised May 12, 2011; accepted May 20, 2011
}

\begin{abstract}
Flash floods occur periodically in Makkah city, Saudi Arabia, due to several factors including its rugged topography and geological structures. Hence, precise assessment of floods becomes a more vital demand in development planning. A GIS-based methodology has been developed for quantifying and spatially mapping the flood characteristics. The core of this new approach is integrating several topographic, metrological, geological, and land use datasets in a GIS environment that utilizes the Curve Number (CN) method of flood modelling for ungauged arid catchments. Additionally, the computations of flood quantities, such as depth and volume of runoff, are performed in the attribute tables of GIS layers, in order to assemble all results in the same environment. The accomplished results show that the runoff depth in Makkah, using a 50-years return period, range from $128.1 \mathrm{~mm}$ to $193.9 \mathrm{~mm}$ while the peak discharge vary from $1063 \mathrm{~m}^{3} / \mathrm{s}$ to $4489 \mathrm{~m}^{3} / \mathrm{s}$. The total flood volume is expected to reach 172.97 million $\mathrm{m}^{3}$ over Makkah metropolitan area. The advantages of the developed methodology include precision, cost-effective, digital outputs, and its ability to be re-run in other conditions.
\end{abstract}

Keywords: Flood Assessment, Rainfall-Runoff Model, NRCS, GIS, Saudi Arabia

\section{Introduction}

Hazards of flash floods are vital in terms of human lives loss and economical damages. Makkah city, west of Kingdom of Saudi Arabia (KSA), exhibits two unique features that increase the hazardous flood consequences: (1) its topography is very complex; (2) about three million Muslims are gathered annually in Makkah to perform Hajj over a two-week period in the winter, which is the main rainfall season in Saudi Arabia. Due to the increasing interest in flood impacts over the last couple of decades, extensive flood estimation studies have been carried out in different countries, such as USA [1], Egypt [2,3], Nigeria [4], South Korea [5], China [6], and Saudi Arabia $[7,8]$. This paper aims to develop a GIS approach for assessing the flash flood hazards for Makkah metropolitan area, utilizing the most up-to-date and precise available data sets.

\section{Flood Estimation}

Flood estimation methods aim to model the rainfall-runoff relationships, and can be categorized into three groups according to their complexity. Simple approaches, such as the rational method and empirical formulas, estimate the peak discharge quickly and with little number of inputs. The Curve Number $(\mathrm{CN})$ is an example of moderate flood estimation methods. Detailed, or complex, models are able to identify the causes of problems rather than producing a simple description of overall conditions [9]. The CN method is quite used in engineering design and flood management projects, particularly in the USA [10-13].

Geographic Information Systems (GIS) and Remote Sensing (RS) techniques have been utilized as efficient tools in flood risk assessment $[14,15]$. For example, Change et al. [16] applied GIS to study the time-based 
relationship between flood hazards and land use changes. Also, Jasrotia and Singh [17] uutilized the CN method to study the runoff and soil erosion within a GIS environment. Moreover, Chen et al. [18] tested a GIS model, which consists of a storm-runoff model and an inundation model, to model flood hazards. In addition, Dongquan et al. [19] developed a GIS batch process to delineate catchments and compute their geomorphologic parameters. Furthermore, Guptaa, and Panigrahya [20] has utilized several data sources and two runoff models in a GIS platform to investigate the flood characteristics and variations of large basins in India. Additionally, Gogoase et al. [21] utilized GIS to develop inundation maps foe extreme flood events. Moreover, Karmakar et al. [22] proposed a methodology for six major damage centers in the Upper Thames River watershed, Canada to assess the flood risks, i.e. flood probability of occurrence, vulnerability to flood, and exposures of land use and soil type to flood.

\section{Flash Floods in Makkah City}

Makkah city is located in the south-west part of KSA, about $80 \mathrm{Km}$ east of the Red Sea (Figure 1). It extends from $39^{\circ} 35^{\prime} \mathrm{E}$ to $40^{\circ} 02^{\prime} \mathrm{E}$, and from $21^{\circ} 09^{\prime} \mathrm{N}$ to $21^{\circ} 37^{\prime}$ $\mathrm{N}$. The area of the metropolitan region (the study area) equals 1593 square kilometres. The topography of Makkah is complex in nature, and several mountainous areas exist inside its metropolitan area. The winter is considered as the main rainy season in Saudi Arabia. The annual rain over Makkah city, for a period extending from
1966 to 2009 , varies from $3.8 \mathrm{~mm}$ to $318.5 \mathrm{~mm}$, with an average of rainfall equals $101.2 \mathrm{~mm}$ (Figure 2). Due to the complexity of Makkah's topography, flash floods occur periodically with significant variations in magnitude. Mirza and Ahmed [23] have reported that the extreme flood type is repeated with a return period of 46 years, while a second-order flood takes place occasionally with a return period of 33 years, and a low-dangerous flood comes about every 13 years. Using the magnitude of the annual rain average (which equals $101.2 \mathrm{~mm}$ ) as a rain intensity factor might not be optimum in flood estimation process. The rain intensity of a single extreme storm may exceed the annual rainfall average for a year. For example, the 1969 storm records (Figure 3) showed that the rain intensity reaches $107.5 \mathrm{~mm} /$ hour during the first 10 minutes of that storm. Based on records of a single rainfall station, this extreme storm resulted in a runoff volume of more than 41 million cubic meters in the central area of Makkah city, with results of severe damages and human loses [23].

Analyzing the flood series frequency, the return period or recurrence interval can be computed. That period defines the average number of years during which a flood of a given magnitude will be equalled or exceeded once. The Welbull method, among several other formulas, computes the return period $T$ as [24]:

$$
T=(n+1) / m
$$

where $n$ is the number of events, or number of records, $m$ is the order or rank of the event (flood item) when flood magnitudes ranked in descending order.

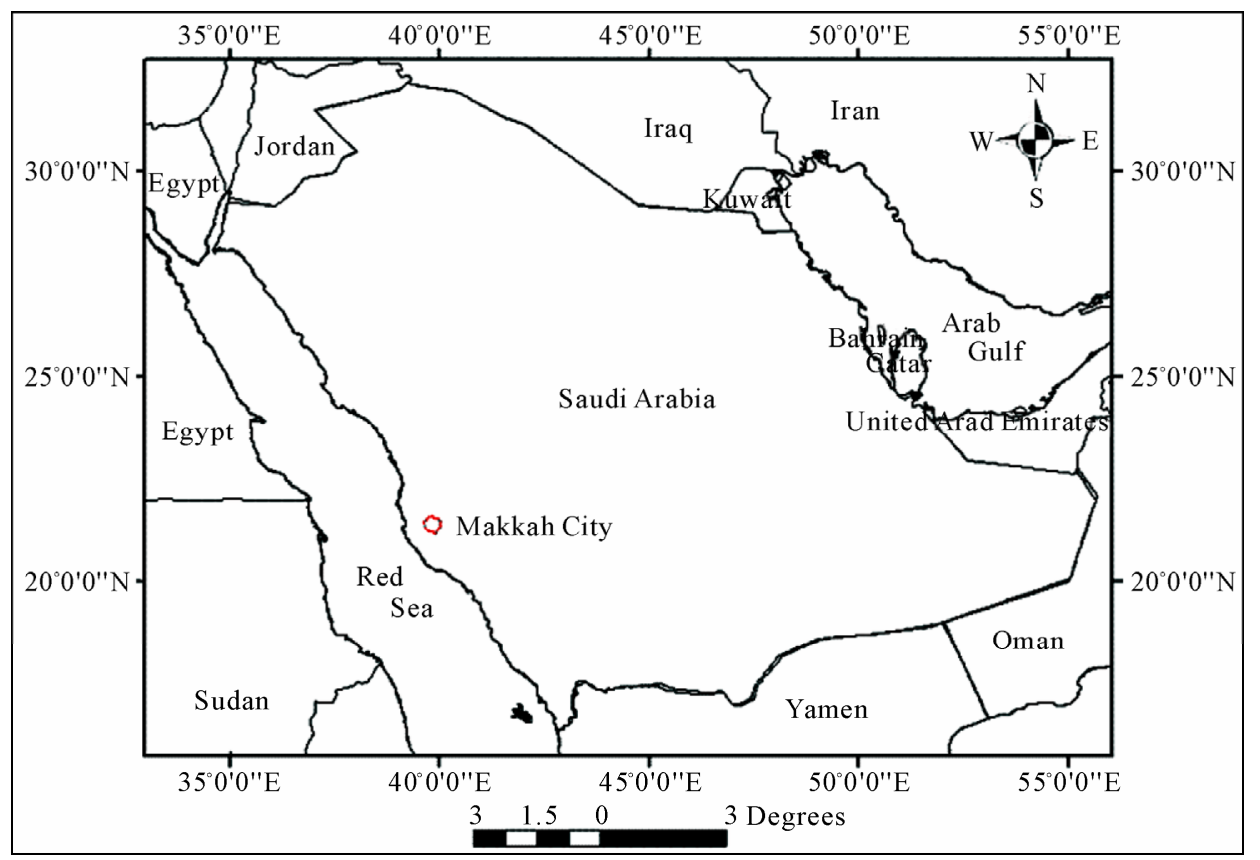

Figure 1. Study area. 


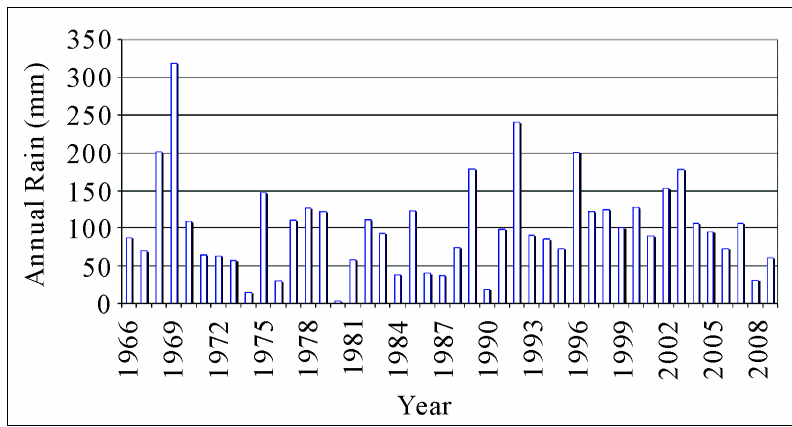

Figure 2. Annual rains in Makkah city from 1966 to 2009.

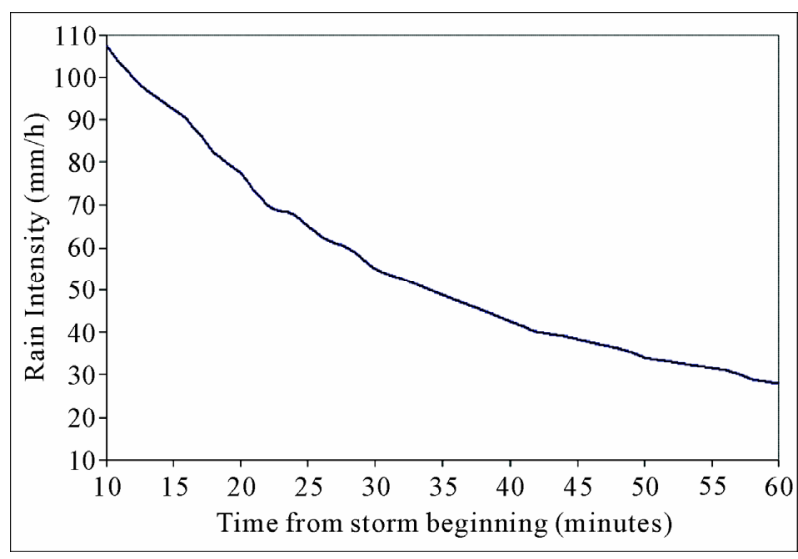

Figure 3. Rain intensity of the 1969 storm in Makkah city.

The computed return period of the 1969's flood has been estimated to 44 years. That piece of information is quite helpful in flood assessment studies, as it means that: 1) that flood magnitude is expected to occur by about 2013; and 2) selected return period value for flood management projects should be equal or greater than 44 years. The rainfall intensity for a 50-years return period has been estimated as $200 \mathrm{~mm} / \mathrm{h}$ [25] and is used in the current research study.

\section{Data and Methodology}

Several datasets have been collected for flood assessment in Makkah city. The main data set is a Digital Elevation Model (DEM) over the study area. This DEM was produced by the by King Abdulaziz City of Sciences and Technology (KACST) with a spatial resolution equals to 5 meters. A window covering Makkah metropolitan area (Figure 4) has been provided through the Center of Excellence in Hajj and Omrah, Umm Al-Qura university. Mirza et al. [26] confirm that this national DEM is 3 times more accurate than previously published global DEMs (e.g. ASTER and SRTM) over Makkah area. From Figure 4, it can be noticed that the heights of Makkah metropolitan area range from 80 to 982 meters. The other datasets include digital geological, soil, and

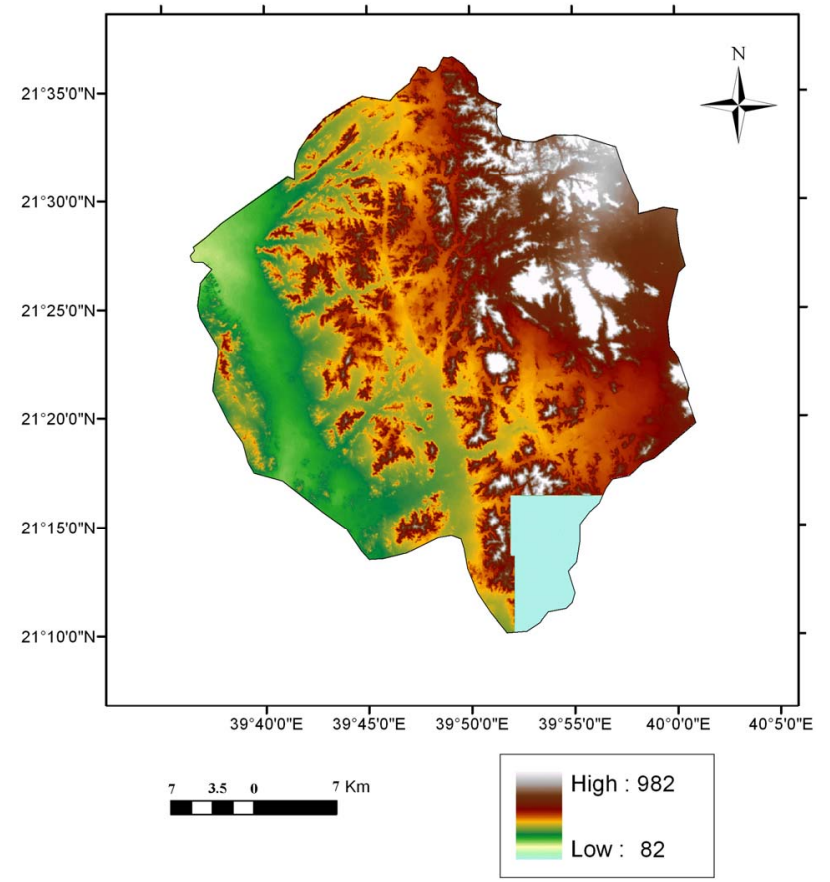

Figure 4. The national 5-m DEM for Makkah city.

land use maps of the study area.

The developed GIS-based flood assessment methodology consists of several stages. Figure $\mathbf{5}$ depicts an overview flow chart of that scheme. In the first stage, the Arc GIS software along with the Arc Hydro extension are used to obtain several shapefiles describing the geomorphology of the study area. These shapefiles include: the main basins and the sub-basins of each main catchment, along with drainage network using Strahler method (a simple widely-utilized network order method), and the longest stream path in each catchment. The second stage of the developed methodology is based on the flood assessment method developed by the US Natural Resources Conservation Service (NRCS), formerly known as the Soil Conservation Service (SCS). It worth mentioning that there are several hydrologic methods used for flood estimation, but the SCS method has been applied in the current research study. This method, also known as the Curve Number (CN), makes use of geological information to assign a unique $\mathrm{CN}$ value for each area, which will be further used to estimate the surface runoff depth and the peak discharge magnitude. VBA is used to compute the required flood defining parameters that consists of [27]:

$$
\begin{gathered}
Q=(P-0.2 S) 2 /(P+0.8 S) \\
S=25.4((1000 / C N)-10) \\
Q T=Q A \\
q p=q u A Q
\end{gathered}
$$




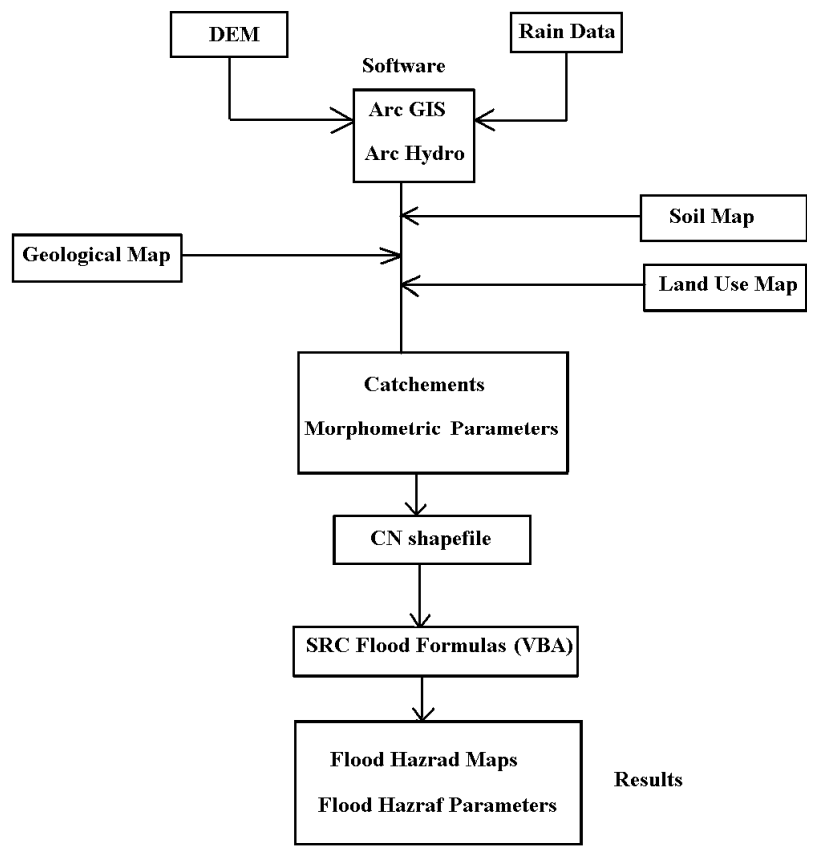

Figure 5. The developed GIS-based flood assessment methodology.

where: $Q$ is the depth of direct runoff $(\mathrm{mm}), P$ is the depth of precipitation for a specific return period $(\mathrm{mm})$, $\mathrm{S}$ is the maximum potential retention $(\mathrm{mm}), C N$ is the curve number, $Q T$ is the volume of runoff $\left(\mathrm{m}^{3}\right), A$ is the Area of basin $\left(\mathrm{Km}^{2}\right), Q$ is the depth of direct runoff $(\mathrm{m})$, $q p$ is the peak discharge $\left(\mathrm{m}^{3} / \mathrm{s}\right)$, and $q u$ is the unit peak discharge $\left(\mathrm{m}^{3} / \mathrm{s} / \mathrm{km}^{2} / \mathrm{mm}\right)$ that can be interpolated from a specific charts [28] or computed from corresponding tables [13].

It worth mentioning that $\mathrm{P}$ was computed through statistical analysis of rainfall records (e.g. by Log Pearson III method) to determine the expected rainfall depth for a specific storm to be occurred again with the same magnitude.

Other hydrological parameters include:

$$
\begin{gathered}
v=0.2279 L / t c \\
t c=1.67\left[L^{0.8}(S+1)^{0.7}\right] /\left[1900 * S L^{0.5}\right] \\
S d=0.133 T C
\end{gathered}
$$

where $v$ is the flow velocity $(\mathrm{m} / \mathrm{s}), L$ is the basin length (expressed in units of meters), tc is the concentration time (minutes) that can be estimated using several formulas, one of them (NRCS method) is given in Equation (7), $S L$ is the average watershed land slope in percentage, and $S d$ is the storm duration (hours).

\section{Results}

The developed GIS-based methodology has been carried out using the available datasets of Makkah metropolitan area. Results of the first stage include several maps and the estimation of many morphometric parameters. It has been found that there are 6 main catchments in Makkah, whose areas range from 74.3 to 360.6 square kilometres, and lengths of their main streams vary from 16.50 to 48.55 kilometres (Figure 6). Table 1 presents statistics of some morphometric parameters of the six catchments.

The second stage of the developed approach results is the determination of flood characteristics in Makkah city. The computations have performed using the depth of precipitation $(P)$ equals $200 \mathrm{~mm}$ for a return period of 50 years. That value is the result of the Log Pearson III statistical analysis for the available rainfall datasets of Makkah city. Additionally, the unit peak discharge ( $q u$ in Equation (4)) has been computed through the equation and tables provided in [13]. Table 2 and Figure 7 present the flood estimated parameters.

Moreover, the peak discharge values found to vary from $1063 \mathrm{~m}^{3} / \mathrm{s}$ (for catchment C2) to $4489 \mathrm{~m}^{3} / \mathrm{s}$ (for catchment C5). Additionally, the runoff depths of the six basins vary from $151.7 \mathrm{~mm}$ to $178.8 \mathrm{~mm}$. The flood volume range between $13.28 \mathrm{~m}^{3}$ (for catchment 3 ) and $54.69 \mathrm{~m}^{3}$ (for catchment 3), with a total of 172.97 million $\mathrm{m}^{3}$ over Makkah metropolitan area.

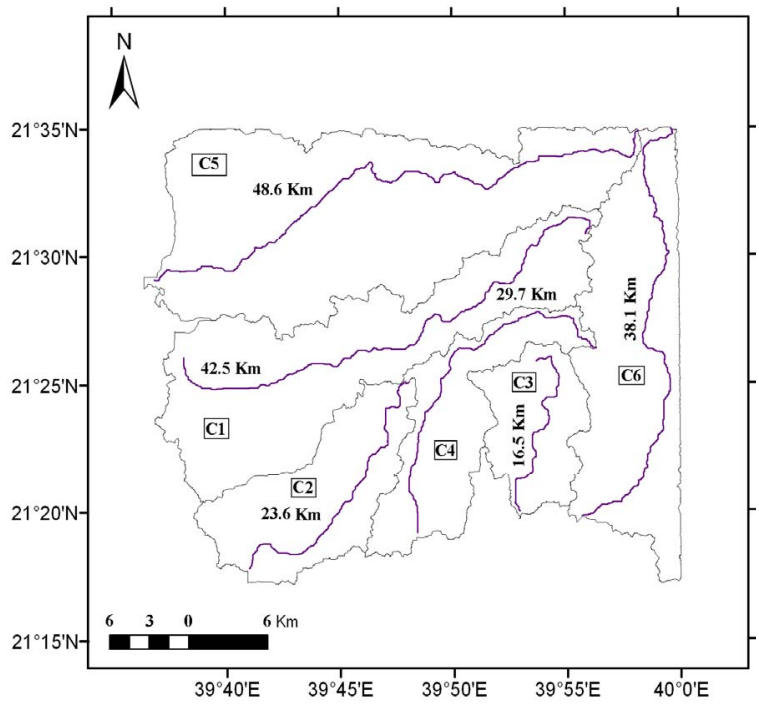

Figure 6. Catchments and their main streams.

Table 1. Statistics of morphometric quantities.

\begin{tabular}{ccccccc}
\hline Item & C1 & C2 & C3 & C4 & C5 & C6 \\
\hline Basin Area $\left(\mathrm{km}^{2}\right)$ & 252.7 & 122.3 & 74.3 & 109.9 & 360.6 & 200.2 \\
Basin Premier (km) & 134.6 & 69.13 & 50.23 & 89.09 & 134.76 & 102.03 \\
Basin Length (km) & 42.48 & 23.64 & 16.50 & 29.70 & 48.55 & 38.13 \\
\hline
\end{tabular}




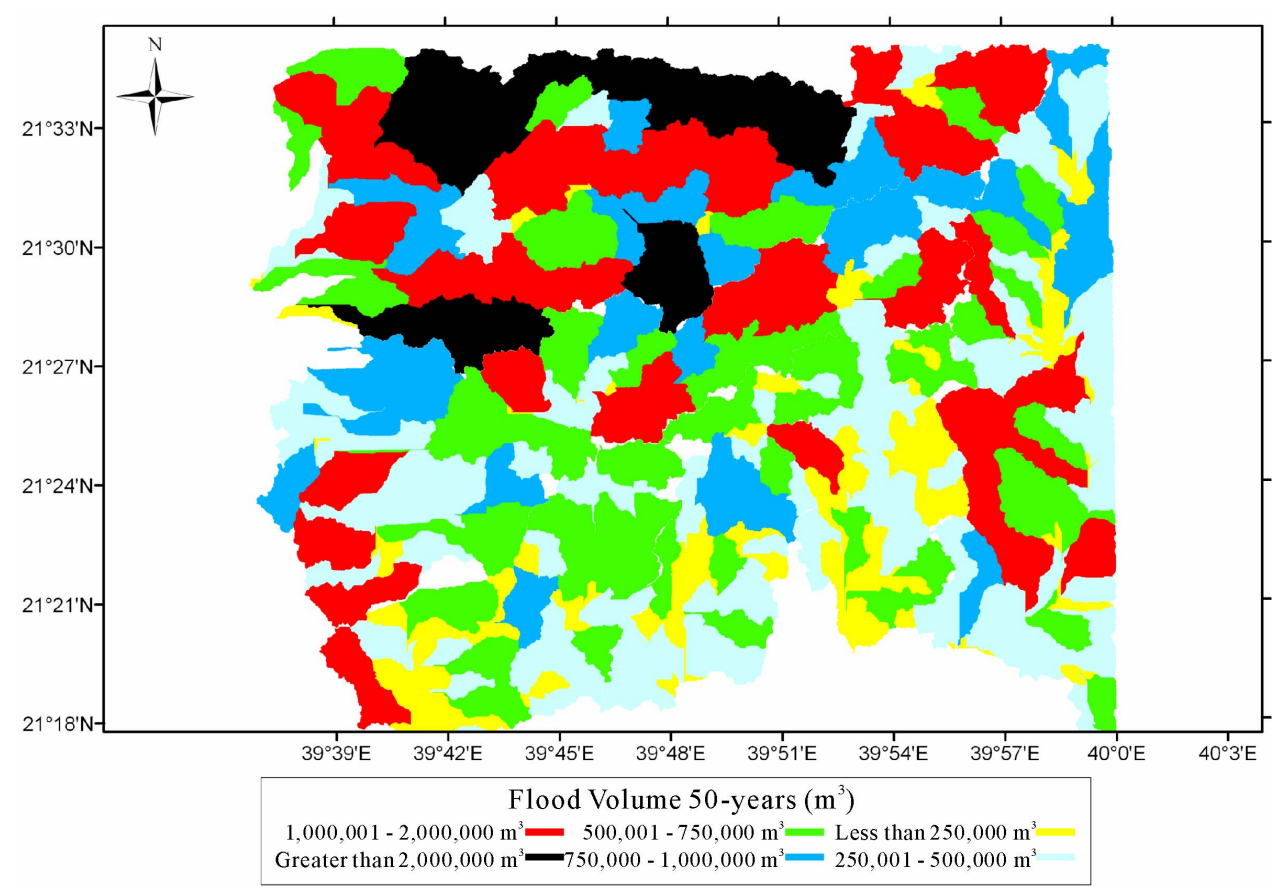

Figure 7. Flood spatial variations in Makkah.

Table 2. Flood characteristics in Makkah city (for a 50years return period).

\begin{tabular}{|c|c|c|c|c|c|c|}
\hline Item & $\mathrm{C} 1$ & $\mathrm{C} 2$ & $\mathrm{C} 3$ & $\mathrm{C} 4$ & $\mathrm{C} 5$ & C6 \\
\hline $\begin{array}{l}\text { Time of concentration } \\
\text { (hours) }\end{array}$ & 5.69 & 3.76 & 1.73 & 2.63 & 6.72 & 4.17 \\
\hline $\mathrm{CN}$ & 84 & 84 & 93 & 89 & 84 & 83 \\
\hline Runoff depth (mm) & 151.7 & 151.7 & 178.8 & 166.7 & 151.7 & 148.8 \\
\hline Peak discharge $\left(\mathrm{m}^{3} / \mathrm{s}\right)$ & 1554 & 1063 & 1307 & 1234 & 4489 & 1514 \\
\hline Storm duration (hour) & 0.76 & 0.50 & 0.23 & 0.35 & 0.89 & 0.56 \\
\hline Flow velocity $(\mathrm{m} / \mathrm{s})$ & 28.34 & 23.86 & 36.19 & 42.87 & 27.44 & 34.68 \\
\hline $\begin{array}{l}\text { Volume of runoff } \\
\left(\text { million } \mathrm{m}^{3}\right)\end{array}$ & 38.34 & $\begin{array}{r}18.55 \\
\text { Total }\end{array}$ & $\begin{array}{r}13.28 \\
=172 .\end{array}$ & 18.32 & 54.69 & 29.79 \\
\hline
\end{tabular}

\section{Discussion}

First, it can be noticed that catchment $\mathrm{C} 3$ has the lowest concentration time (1.98 hours), which is the time for runoff to travel from the most distant point to the outlet point. The lower time of concentration, the more hazardous is the runoff. Additionally, catchment $\mathrm{C} 3$ is expected to have minimum storm duration ( 0.26 hours) while catchment $\mathrm{C} 1$ has the maximum value ( 0.80 hours). Concerning the flow velocity of the six basins, it has been found that the values range from $22.44 \mathrm{~m} / \mathrm{s}$ (for catchment C2) to $73.37 \mathrm{~m} / \mathrm{s}$ (for catchment C5).

Keeping in mind that the lower concentration time, the more hazardous is the runoff, it has been found that catchment $\mathrm{C} 3$ has the lower concentration time That is an excepted result, since catchment $\mathrm{C} 3$ has the highest relief ratio $(40.43 \mathrm{~m} / \mathrm{km})$ even though it does not have the highest flow velocity. Additionally, catchment $\mathrm{C} 3$ is expected to have minimum storm duration ( 0.26 hours) while catchment $\mathrm{C} 1$ has the maximum value ( 0.80 hours). It is worth mentioning that the storm duration is a function of the concentration time as seen in Equation (8).

A coloration analysis was performed between the main flood factors. The correlation matrix is presented in Table 3. Concerning the flow velocity of the six basins, it has been found that the minimum velocity belongs to catchment $\mathrm{C} 2$ while the maximum velocity is for catchment C5. Equation (5) shows that the flow velocity is directly proportional to the catchment stream length, and is inversely proportional to the concentration time. The same conclusion is drawn from Table 3 where the peak discharge, total flood volume, basin area, and basin stream length have positive strong correlations with the flow velocity $(0.97,0.76,0.74$, and 0.61 respectively), while the concentration time has a negative moderate correlation $(-0.48)$.

Second, catchment $\mathrm{C} 3$ also has the highest $\mathrm{CN}$ value of 93 . The higher $\mathrm{CN}$ values, in the study area, is attributed to two factors: 1) the residential area of Makkah city, paved streets, was assigned $\mathrm{CN}$ of 98 that reflects the low permeability of rains; 2) a great portion of Makkah's geology consists of Pre-Cambrian igneous and metamorphic rocks, that get relatively high $\mathrm{CN}$ according to 
Table 3. Correlation between main flood characteristics.

\begin{tabular}{cccccccc}
\hline & $C N$ & $t c$ & $A$ & $L$ & $Q$ & $Q T$ & $v$ \\
\hline$C N$ & 1 & & & & & & \\
$t c$ & -0.65 & 1 & & & & & \\
$A$ & -0.66 & 0.21 & 1 & & & & \\
$L$ & -0.72 & 0.39 & 0.94 & 1 & & & \\
$Q$ & -0.30 & -0.33 & 0.85 & 0.70 & 1 & & \\
$Q T$ & -0.62 & 0.18 & 0.9987 & 0.94 & 0.87 & 1 & \\
$v$ & -0.14 & -0.48 & 0.74 & 0.61 & 0.97 & 0.76 & 1 \\
\hline
\end{tabular}

where: $C N$ is the curve number, $t c$ is the time of concentration, $A$ is the basin area, $L$ is the basin stream length, $Q$ is runoff depth, $Q T$ is the runoff volume, and $\mathrm{v}$ is the runoff velocity.

the SRC classification.

Moreover, it can be noticed that four catchments $(\mathrm{C} 1$, $\mathrm{C} 2, \mathrm{C} 5$, and $\mathrm{C} 6$ ) have similar $\mathrm{CN}$ values, but $\mathrm{C} 2$ has the least basin area. That leads to this catchment produces the minimum peak discharge. As expected, catchment C5 produces the highest peak discharge because of its big basin area. Table 3 concludes the same result since the basin area and basin stream length has strong correlations $(0.85$ and 0.70$)$ with the peak discharge.

Additionally, it can be concluded that the highest runoff depth belong to catchment $\mathrm{C} 3$, which has the highest $\mathrm{CN}$ value. Regarding the flood volume, it can be seen that catchment $\mathrm{C} 5$ produces the biggest value due to the fact that it has the biggest area $\left(360.6 \mathrm{~km}^{2}\right)$. The correlation between flood volume and basin area is strong (0.9987) as seen in Table 3.

The GIS-based CN flood estimation methodology has several advantages. First, it incorporates many input datasets including metrological, geological, soil, land use, and DEM. Other approaches (e.g. the rational method) employ less input items, while some national regression models used in Saudi Arabia depend only on the basin area to estimate expected flood. Dawod et al. [29] concluded that the $\mathrm{CN}$ method is more precise than some other flood estimation methods over Makkah region. Moreover, this paper presents a GIS-based implementation of the $\mathrm{CN}$ methodology where computations have been performed in the attribute tables within the GIS environment (using VBA). So, the flood estimation process is efficient, faster, and can be easily performed for several scenarios and even for several regions in Saudi Arabia once the required input layers are available.

\section{Conclusions}

Makkah metropolitan area, south west of Saudi Arabia, is distinguished by two items (a complex topography and the gathering of about three million Muslims to perform Hajj over a specific short time period annually) that greatly raises awareness of flood hazards impacts. This research develops a GIS-based approach for mapping and quantifying flood assessment measures. The developed methodology is based on integrating several datasets in a GIS environment utilizing the SRC CN flood modelling method. Results show that the main factors affect the total flood volumes, in Makkah metropolitan area, are the catchment area, the basin stream length, and the peak discharge. Additionally, it has been concluded that the higher $\mathrm{CN}$ value (for low permeability soil, geological, and land use features), the higher runoff and flood hazards. Merits of that methodology include precision, cost-effective, digital outputs, and its ability to be re-run for other scenario (e.g., other design return period). Hence, it is recommended that the attained results be utilized in governmental planning in Makkah city, and that approach should be applied to all other cities in Saudi Arabia.

\section{Acknowledgements}

The authors would like to acknowledge the financial support offered by the Center of Research Excellence in Hajj and Omrah (Hajjcore), Umm Al-Qura university, Saudi Arabia.

\section{References}

[1] USGS (U.S. Geological Survey), "Watershed Models for Decision Support for Inflows to Potholes Reservoir," Washington Scientific Investigations Report 2009-5081, 2009.

[2] M. Azab, “Assessment and Management of Natural Hazards and Disasters along Qena-Safaga Road, Central Eastern Desert, Egypt," Egyptian Journal of Remote Sensing and Space Science, Vol. 12, 2009, pp. 55-70.

[3] M. El-Bastawesy, K. White and A. Nasr, "Integration of Remote Sensing and GIS for Modelling Flash Floods in Wadi Hudain Catchment, Egypt," Hydrological Process, Vol. 23, No. 9, 2009, pp. 1359-1368. doi: $10.1002 /$ hyp. 7259

[4] S. Yahaya, N. Ahmad and R. Abdalla, "Multicriteria Analysis for Flood Vulnerable Areas In HadejiaJama'are River Basin, Nigeria," European Journal of Scientific Research, Vol. 42, No. 1, 2010, pp. 71-83.

[5] N. Kim, J.W. Lee, J., Lee and J. E. Lee, "SWAT Application to Estimate Design Runoff Curve Number for South Korean Conditions," Hydrological Process, Vol. 24, No. 15, 2010, pp. 2156-2170.

[6] W. Liang, C. Yongli, C. Hongquan, D. Daler, Z. Jingmin, and Y. Juan, "Flood Disaster in Taihu Basin, China: Causal Chain and Policy Option Analyses," Environmental Earth Science, Vol. 63, No. 5, 2010, pp. 1119 


\section{4. doi:10.1007/s12665-010-0786-X}

[7] M. Al Saud, "Assessment of Flood Hazard of Jeddah Area 2009, Saudi Arabia," Journal of Water Resource and Protection, Vol. 2, No. 9, 2010, pp. 839-847. doi:10.4236/jwarp.2010.29099

[8] E. Fred and B. Mostafa, "Flood Risk Modeling for Holy Sites in Makkah," Proceedings of the Symposium on National GIS application in Saudi Arabia, Al-Kober City, 2008, pp. 1-12.

[9] E. Mihalik, "Watershed Characterization and Runoff Modelling of the Chapel Branch Creek, Orangeburg county, South Carolina," MS.C Thesis, College of Charleston, Charleston, 2008.

[10] IDoT (Iowa State Department of Transportation), "Iowa Storm Water Management Manual,” 2009.

[11] US ACE (US Army Corps of Engineers), "Physical Stream Assessment," 2004.

[12] NH DoT (New Hampshire Department of Transportation), "Drainage Design Manual for Highways," 1998.

[13] US DoT (US Department of Transportation), "Highway Hydrology Manual," Publication No. FHWA-02-001, 2002.

[14] A. Youssef, B. Pradhan and A. Hassan. "Flash Flood Risk Estimation along the St. Katherine Road, Southern Sinai, Egypt Using GIS Based Morphometry and Satellite Imagery," Environmental Earth Science, Vol. , No. , April 27, 2010, pp. 1-13.

[15] A. Saleh and S. Al-Hatrushi. "Torrential Flood Hazards Assessment, Management, and Mitigation, in Wadi Aday, Muscat area, Sultanate of Oman, a GIS \& RS Approach," Egyptian Journal of Remote Sensing and Space Sciences, 12, No. 1, 2010, pp. 71-86.

[16] H. Chang, J. Franczyk and C. Kim, "What is Responsible for Increasing Flood Risks? The Case of Gangwon Province, Korea," Natural Hazards, Vol. 48, No. 3, 2009, pp. 339-354. doi:10.1007/s11069-008-9266-y

[17] A. Jasrotia and R. Singh, "Modeling Runoff and Soil Erosion in a Catchment Area, Using the GIS, in the Himalayan Region, India," Environmental Geology, Vol. 51, No. 1, 2006, pp. 29-37. doi:10.1007/s00254-006-0301-6

[18] J. Chen, A. Hill and L. Urbano, "A GIS-Based Model for Urban Flood Inundation," Journal of Hydrology, Vol. 373, No. 1-2, 2010, pp. 184-192. doi:10.1016/j.jhydrol.2009.04.021

[19] Z. Dongquan, C. Jining, W. Haozheng, T. Qingyuan, C. Shangbing and S. Zheng, "GIS-Based Urban RainfallRunoff Modeling Using an Automatic Catchment- Discretization Approach: A Case Study in Macau," Environmental Earth Sciences, Vol. 59, No. 2, 2009, pp. 465472. doi:10.1007/s12665-009-0045-1

[20] P. Guptaa and S. Panigrahya, "Geo-Spatial Modeling of Runoff of Large Land Mass: Analysis, Approach and Results for Major River Basins of India," Proceedings of the International Archives of the Photogrammetry, Remote Sensing and Spatial Information Sciences, Vol. 37, Part B2, Beijing, 2008.

[21] D. Gogoase, I. Armaş and C. Ionescu, "Inundation Maps for Extreme Flood Events at the Mouth of the Danube River," International Journal of Geosciences, Vol. 2, No. 1, 2011, pp. 68-74.

[22] S. Karmakar, S. Simonovic, A. Peck and J. Black, "An Information System for Risk-Vulnerability Assessment to Flood," Journal of Geographic Information System, Vol. 2, No. 2, 2010, pp. 129-146.

[23] M. Mirza and B. Ahmed, "Winter Weather and Climate Conditions in Makkah (in Arabic)," Geographic Messages, Kuwait Geographic Association, Kuwait, Vol. 253, 2001.

[24] H. Raghunath, "Hydrology: Principles, Analysis, and Design," New Age International Ltd., New Delhi, 2006.

[25] KSA MoPWH (Saudi Ministry of Public Works and Housing), "Storm Water Drainage System for Muzdalifah and Arafat Areas," Unpublished Technical Report, 2001.

[26] M. Mirza, G. Dawod and K. Al-Ghamdi, "Assessment of Global and National Digital Elevation Models For Geodetic and Geomorphologic Applications in Makkah Metropolitan Area, Saudi Arabia," The XXV IUGG General Assembly, Melbourne, 28 June - 7 July, 2011.

[27] Z. Sen, "Wadi Hydrology," CRC Press, New York, 2008.

[28] US NRCS (US National Resources Conservation Services), "Urban Hydrology for Small Watersheds," Technical Manual TR55, 1986.

[29] G. Dawod, M. Mirza and K. Al-Ghamdi, "Assessment of Several Flood Estimation Methodologies in Makkah Metropolitan Area, Saudi Arabia," Under Review, Arabian Journal of Geosciences, 2011. 